\title{
The influence of technogenic factors on the karst activization of Precarpathian salt sediments and karst natural lows
}

\author{
Vasyl Pavliuk \\ Scientific-Research Institute "Galurgiya”; Fabrychna 5a, 77300 Kalush, Ukraine; e-mail: notebooc@gmail.com
}

(C) 2016 Authors. This is an open access publication, which can be used, distributed and reproduced in any medium according to the Creative Commons CC-BY 4.0 License requiring that the original work has been properly cited.

Received: 29 February 2016; accepted: 5 June 2016

\begin{abstract}
The purpose of this article is to conduct an analysis of the technological and natural factors that have influenced the development and intensification of the salt karst, located within Miocene salt-bearing sediments. Understanding the rules of the karst process is one way to help make the right decisions at the forecasting stage of these harmful exogenic geological processes. This is especially true of salt deposits, which are located in complex geological conditions (e.g. the Carpathian Foredeep). The development of the salt karst in the Precarpathian has shown that it is a complex multi-system process, where all the components have a significant impact on the results and they are directly related to each other.

The results of the completed research confirm that the features of the spatial development of the karst processes within the Carpathian salt deposits are caused by the complex geological structures of the Miocene sediments. The spatial developments of the karst processes depend on the heterogeneity of the water penetration in the plans and sections of the salt-bearing deposits. This forms the predominant vector of the underground leaching intensity along the geological boundaries. Permeability and solubility of the salt bearing deposits along the bedding are higher, relative to the permeability and solubility across geological structures. Faults which occur across the strike of geological layers act as a containment of the karst processes along the geological borders.
\end{abstract}

Keywords: salt karst, gypsum-clay cap, Miocene salts, Precarpathians, potash salt mining

\section{INTRODUCTION}

The relevance of the environmental study of the exogenic processes (karst, suffusion, subsidence, flooding, landslides, contamination of soil, surface and groundwater) in the Precarpathian area where influenced by mining activities is connected with the fact that the mentioned processes are unstable and dangerous to both land and life (Blajda \& Górecki 2001, Frumkin 2013). The analysis of the manifestations of the exogenous events within the influence of the potash mines has shown and organized the natural conditions and factors that affect the development of the karst. The intensity of the exogenic geological process (EGP) depends on the scale and peculiarities of the karst development (Pavliuk 2010). A natural linear distribution of karst is found in the course of these works, both on the surface and on the inside of the geological deposits that correspond to the local geological aspects and are in accordance with the structures of the Carpathian region. These systematic patterns are noted throughout the Precarpathians. These dependences lead to the conclusion of the decisive influence of the geological structures on the characteristics of the exogenic events within the region as both natural and man-made states. In each case, the estimation of the salt karst activation or 
the prediction of the effects of the process, along with a complex analysis and the systematization of all the conditions and factors that may have an impact on its development, is required. Studies have shown that salt karst is a complex multi-system process where all the components have a significant impact on the results and are directly related to each other.

\section{METHODS}

The main conclusions of this work are derived from the processing and interpretation of the collected materials from the collections of the Lviv Geological Prospecting Enterprise and the Institute for Scientific Research "Halurhiya" Kalush. These scientific papers are devoted to this subject and were conducted as field observations during the execution of the government program: "The Monitoring of the Wide-spread Development of the Geotechnical EGP Processes and Phenomena Within the Lviv Region". This program was done in order to provide geological maintenance to the GIAS (Government Information-Analytical System) (2006-2011).

The main methods used in the preparation and conduct of this study were:

- analysis of archive data and field methods;

- cooperation with the local government and regional offices of the Ministry of Emergency Situations;

- quantitative and qualitative analysis of the data, its classification, the creation of the appropriate GIS databases in Excel and the MapInfo environment, the comparison, correlation and multidimensional scaling of the results and others;

- verification of the results, allowing us to check the received information through to its final analysis.

The verification and the logical and methodological procedures for establishing the accuracy of the data on the basis of its consistency with the empirical and actual data, has mostly been tested on a computer using the "MapInfo" method of multilayer overlay mapping of the statistical and analytical information, creating diverse factual material in two-dimensional and three-dimensional images.
The purpose of this review is to conduct an analysis of the technological and natural factors that influence the development and the intensification of the salt karst and the harmful exogenic geological processes within the distribution of the Precarpathians salt-bearing Miocene sediments. The basis of the conducted review is to highlight the natural laws of karst development.

\section{SALT KARST}

Overall, karst is quite a complex phenomenon which occurs in arrays of solvent deposits, where the rock dissolution becomes parallel to other hypergenesis processes and results in the formation of a weathered crust formation (Korotkevich 1970). Mainly, the most significant factor of salt karst activation is the anthropogenic activities. The man-made impact, without enough consideration of the geological structure of the deposits, natural laws and the physical properties of salt, can lead to the fact that the speed of the exogenous processes that occur in the undisturbed natural state, are accelerated many times.

Global research into the development and activation of exogenous processes and its impact on salt mines shows that the fundamental principle of that intensification was uncontrolled injection of groundwater and surface water in mine voids. Some examples of recent large-scale accidents would be: Congo-1977; Solikamsk-Berezniki (Russia), 1995-2007; Hope Mine (Germany) - 1984; Ronnenberg-Schmalkalden (Germany), 1976-2010 (Wolkersdorfer 2008).

In total, there have been more than 80 cases like these. In Ukraine, there have been flooded quarry and mines in Kalush, in Mine no. 2 in Stebnyk and catastrophic failures in Solotvyno (Transcarpathia). Regarding the Stebnyk deposits (Fig. 1), the practice of studying the causes of the injection (penetration) of surface water in volumes excavations (mine underground space) showed that in some areas of Mine no. 1 (43/2 drift, crosscut I/I, crosscut 4/I, ort 99/I, underground boreholes 469 and 477) and at Mine no. 2 (ort I/B, crosscut $17 / \mathrm{I}$, the chambers $155 \backslash \mathrm{I}$ and $122 / \mathrm{I})$, geological and hydrogeological conditions were not properly understood during the performance of the underground work and contained no information on 


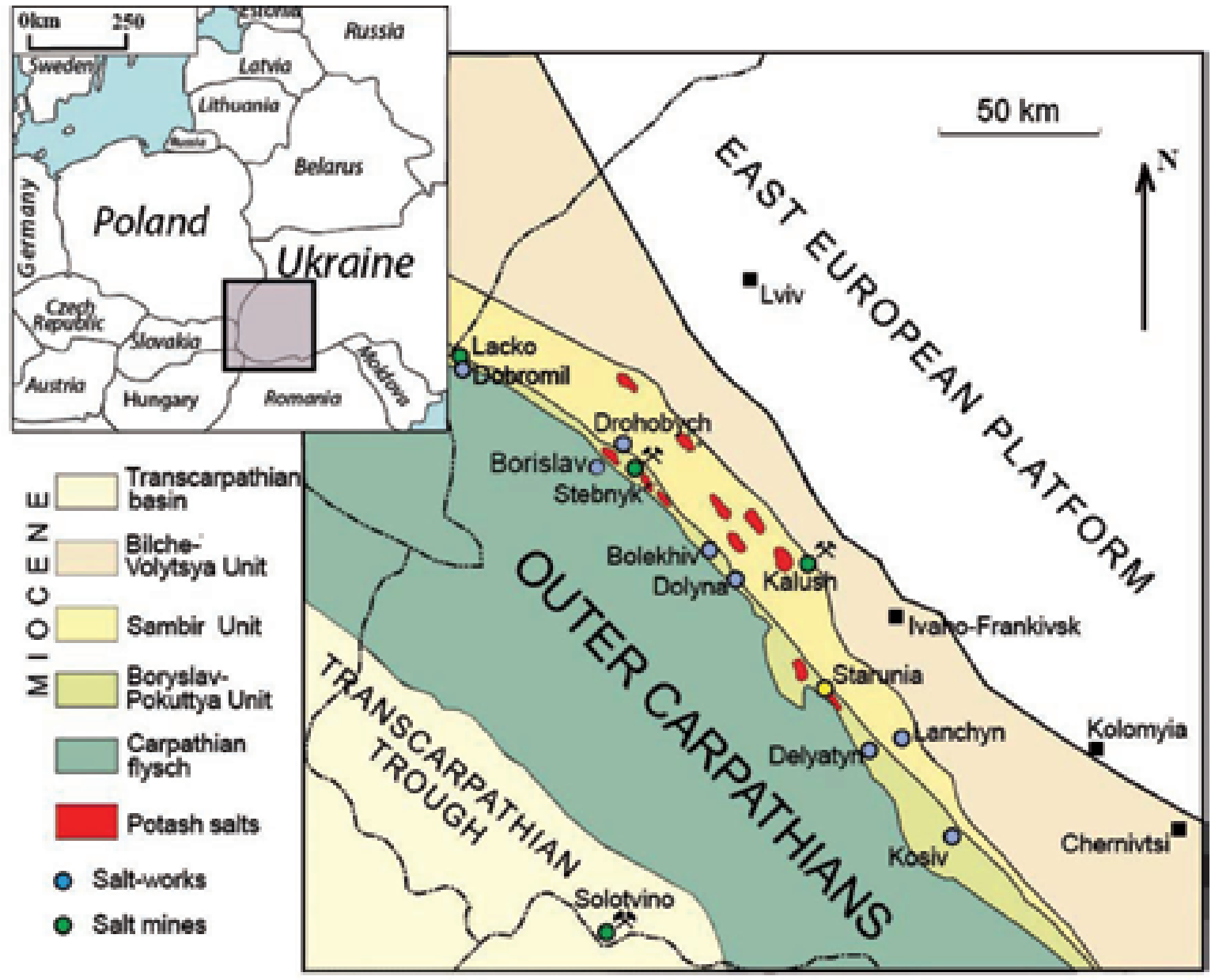

Fig. 1. Distribution of potash and rock salt mines in the Precarpathians (after Bukowski \& Czapowski 2009)

the nature, location and depth of the hazardous areas of surface water penetration, which are supergene altered rocks (zones) (Apsse et al. 1966, Lipnitskiy 1979). These circumstances have led to the insufficient evaluation of the cap pillar waterproof capacity in these areas.

\section{RESULTS AND DISCUSSION}

An analysis of the shaft changes in depth and directions in the upper parts of the deposits (there is a greater threat when the surface water has the ability to discharge in the underground workings), showed that there were cases where the underground workings was performed according to the requirements of economic expediency, and not as a security operation. For example, the "Eastern" Stebnyk mine shaft is located in the base of this part of the surface "salt mirrors". Here, there is a greater possibility of a concentration of infiltrated surface water, which could be one of the main causes of the extensive displays of underground leaks and the formation of collapsed karst on the day surface. It would have been more efficient, in terms of operational safety, to place the mine shaft $100 \mathrm{~m}$ to the northwest, on the highest hypsometric salt surface mirrors of the plot (Figs 2, 3). Moreover, it should be emphasized that the underground mines were purposely created by man-made explosions. Even F. Permyakov, in the Solikamsk mine in 1941, noticed that in the carnallite rock there was a system of concentric cracks which eventually increased. The center of these cracks appears to be the location of these explosions. As a result, cracks were formed and the inrush of rock (the height of which may exceed 5-6 times the height of the roadway) and water increased the density of the deposits (Vakhromeeva 1959). 

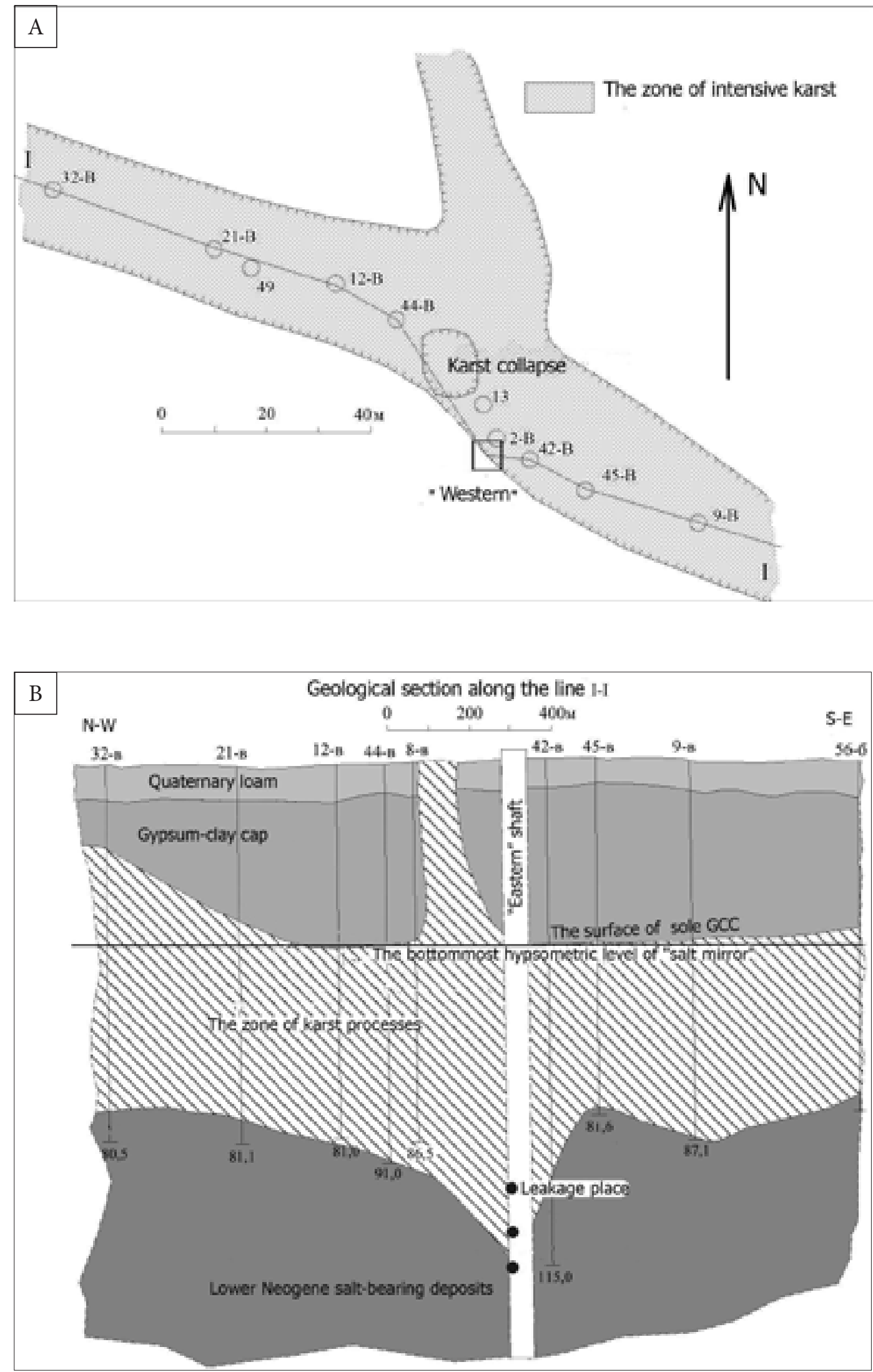

Fig. 2. The location plan (A) and geological cross-section (B) of the shaft "East", Mine no. 2, Stebnyk (Stupnitskiy et al. 1995) 


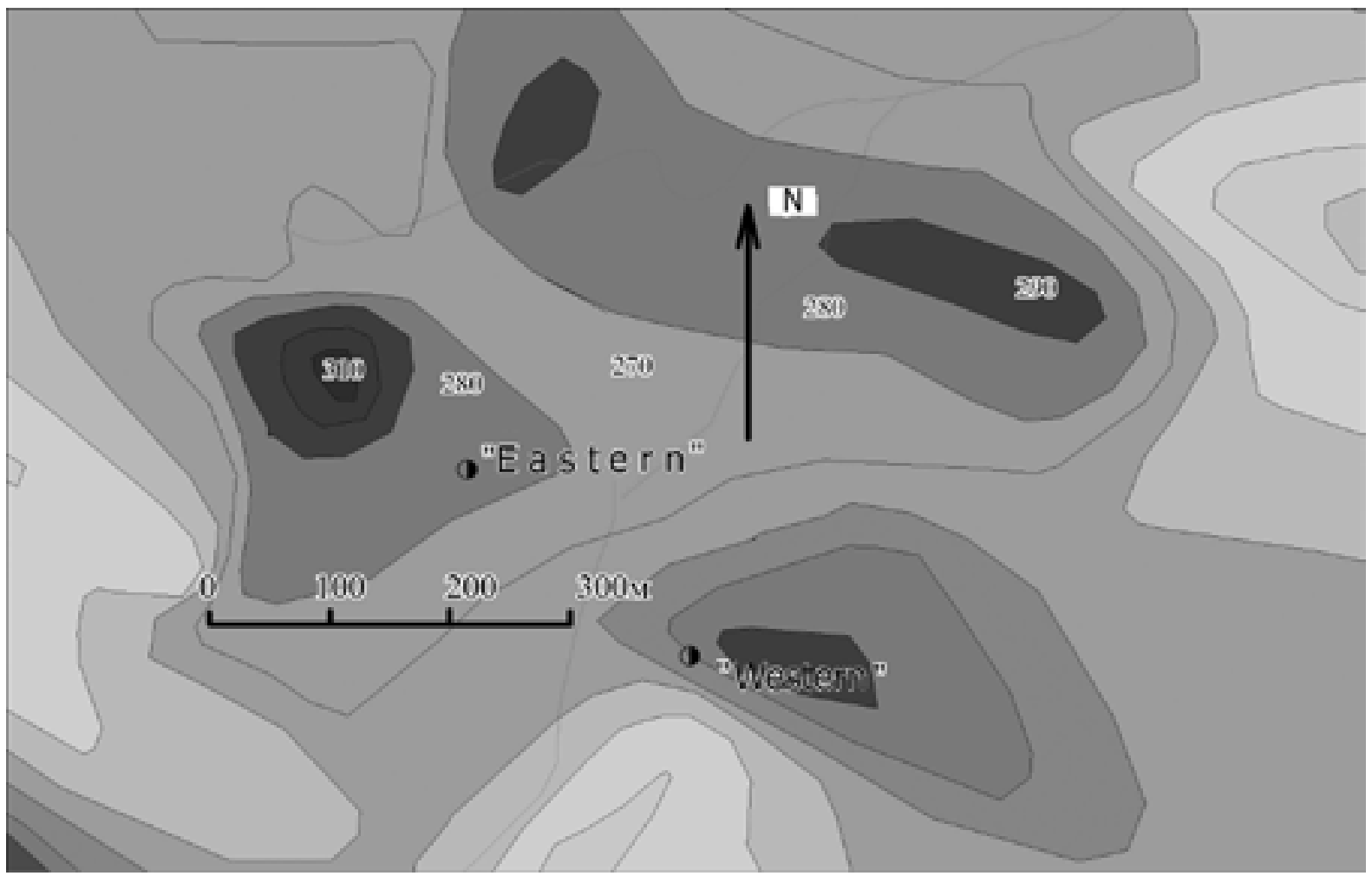

Fig. 3. Hypsometric surface plan of the "salt mirror" in the "Eastern" shaft area, Mine no. 2, Stebnyk (Stupnitskiy et al. 1995)

Examining the formation of the depression funnel within the aquifer sediments of the gypsum-clay cap, we can observe that $100 \%$ of its dependence is on the geological structure of the site. This depression funnel was formed in 1978 as the result of a rush of underground water in the chamber 115 (Fig. 4) which is located on the west side of Mine no. 2 in Stebnyk. Initially, in 1980, it was a relatively isometric shape with a ratio of width to length of about 1: 2 . Furthermore, there is an increase only along the geological boundaries and it is not expanding across structures. Moreover, the development of the water conical depression, in terms of limited time, had stopped when it reached the disjunctive tectonic disturbances that stopped it in a south-easterly direction and warped part of it in the western, north-western side. This confirms earlier assumptions expressed by "the role of transverse faults in the deterrence of salt karst processes along geological boundaries" (Pavliuk 2010a, 2010b). Water conical depressions that naturally grow by the increased permeability of sediments as resulting from the dynamic directed underground aquifer flows in salt-bearing deposits, further developed mainly just on the northwest side, increasing the catchment area and discharging more groundwater into underground workings. Now we have an isometric form, in terms of shape, with a ratio of about 4: 1 and boundaries that fully meet the geological structure of the area (Fig. 4). So, the increase of the permeability sediments, through the development of the karst geological processes along the border is a major factor in the growth of water inflows in the underground workings and not the increase of the catchment area (what repeatedly was spoken before (Stupnitskiy et al. 1995, Gaydin 2008), which in turn was the consequence.

In 1998 a karst collapse formed on Pomiretska Street in Truskavets, within a private residential development (nos. 54 and 56), as a result of backwater groundwater and its hydrogeological regime change that was due to the construction of the Sanatorium "Carpathians" on the east side. The collapse had a depth of $15 \mathrm{~m}$ and an area of $6 \mathrm{~m} \times 4 \mathrm{~m}$. 


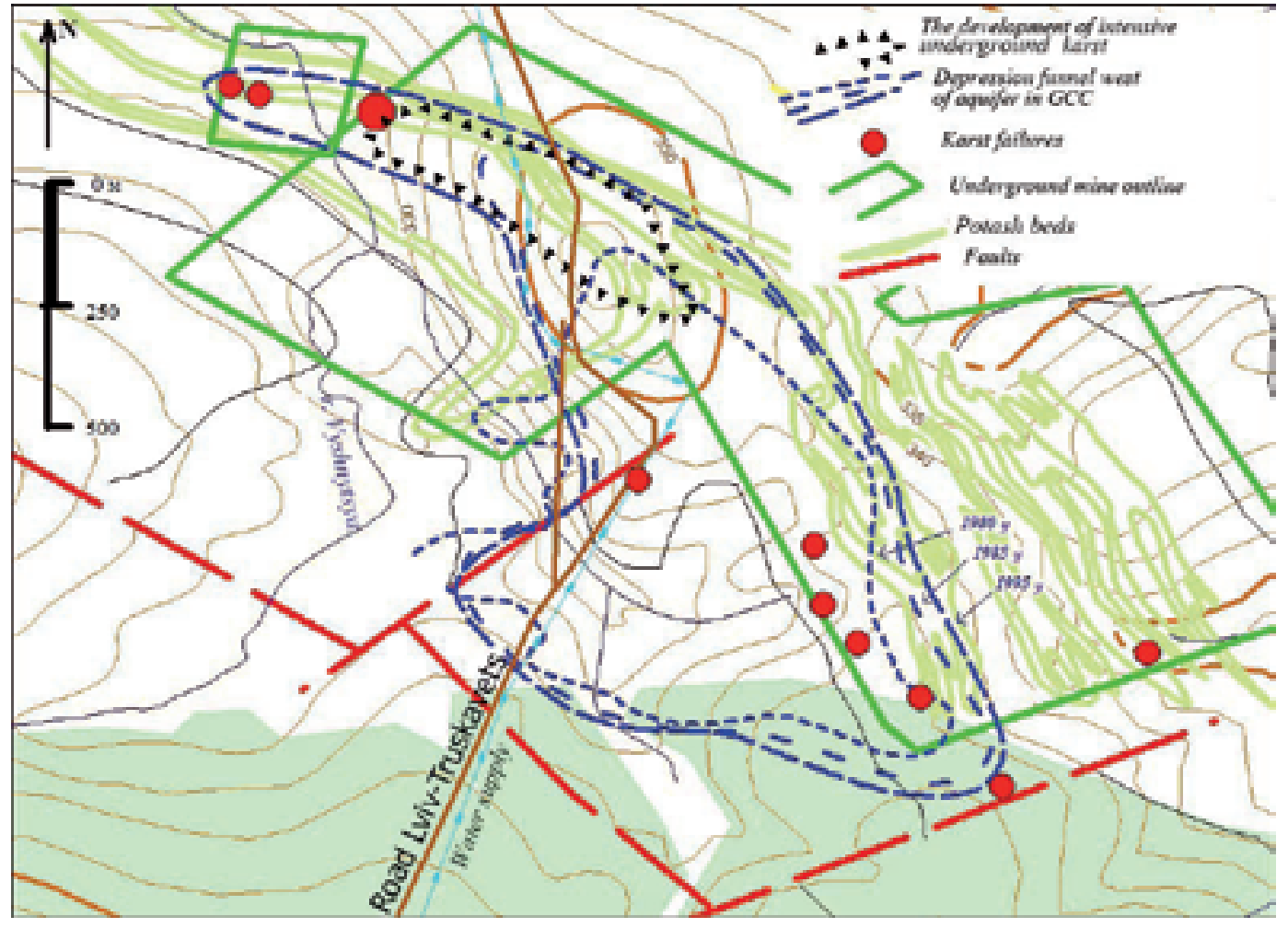

Fig. 4. Location plan showing the development of exogenous processes in the area of the Vyshnytsya River valley, western outskirts of Stebnyk

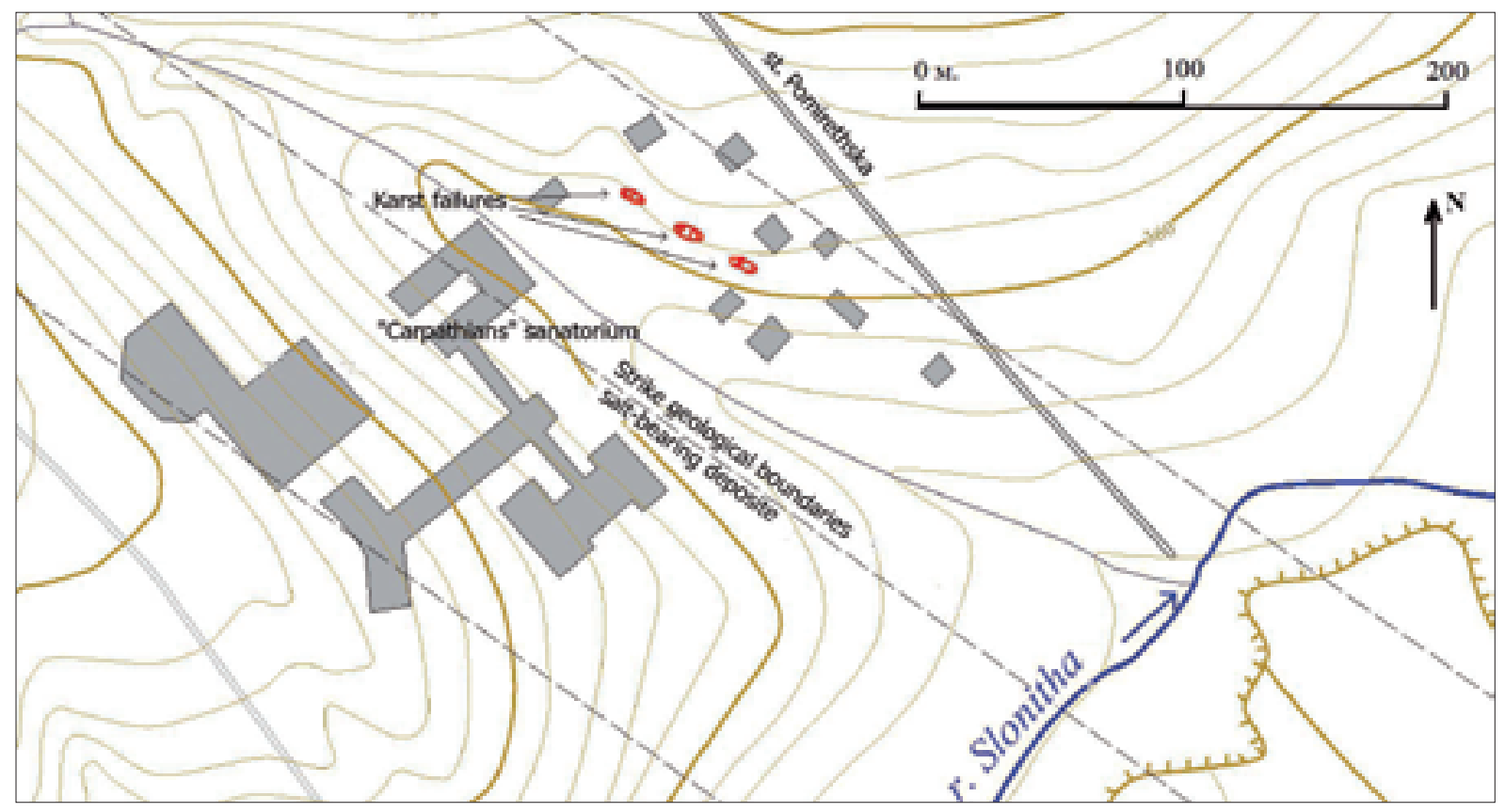

Fig. 5. Location map of karst failures. Pomiretska street, Truskavets 
It was oval, elongated along geological boundaries with underlying salt-bearing sediments and brines filled to a depth of about $1 \mathrm{~m}$ from the earth's surface. After the first collapse in the autumn of 2009, in different time periods within this sector, three similar ones were formed (Fig. 5). They were oval, elongated and placed on a straight line parallel to the strike of geological boundaries.

In 2006, due to a water supply break in Borislav city (Modrychska Street 50) a karst collapse, with a diameter of up to $6 \mathrm{~m}$ and a depth of $4 \mathrm{~m}$, was formed on the road. After repairing the supply break, the karst was covered. During the formation of karst, $30 \mathrm{~m}$ to the northwest of this point (along geological boundaries) at a well depth of $8 \mathrm{~m}$, the water disappeared. Further along another $20 \mathrm{~m}$, a small surface dip formed with a diameter of $1.5 \mathrm{~m}$ and a depth of $1 \mathrm{~m}$, which no one paid attention to. Obviously, when the water leaked from the supply line along this geological structure, it formed a cavern, up to 50-70 $\mathrm{m}$ long, underneath apartment building number 50 and storing well and then as brine after $120 \mathrm{~m}$ into the Tysmenytsia flood plain where it was discharged. The situation remained stable until the autumn of 2009, when under a house, located $15 \mathrm{~m}$ from the water supply break (along the geological boundary), the earth's surface collapsed, but was restrained by the building's foundation (Fig. 6).
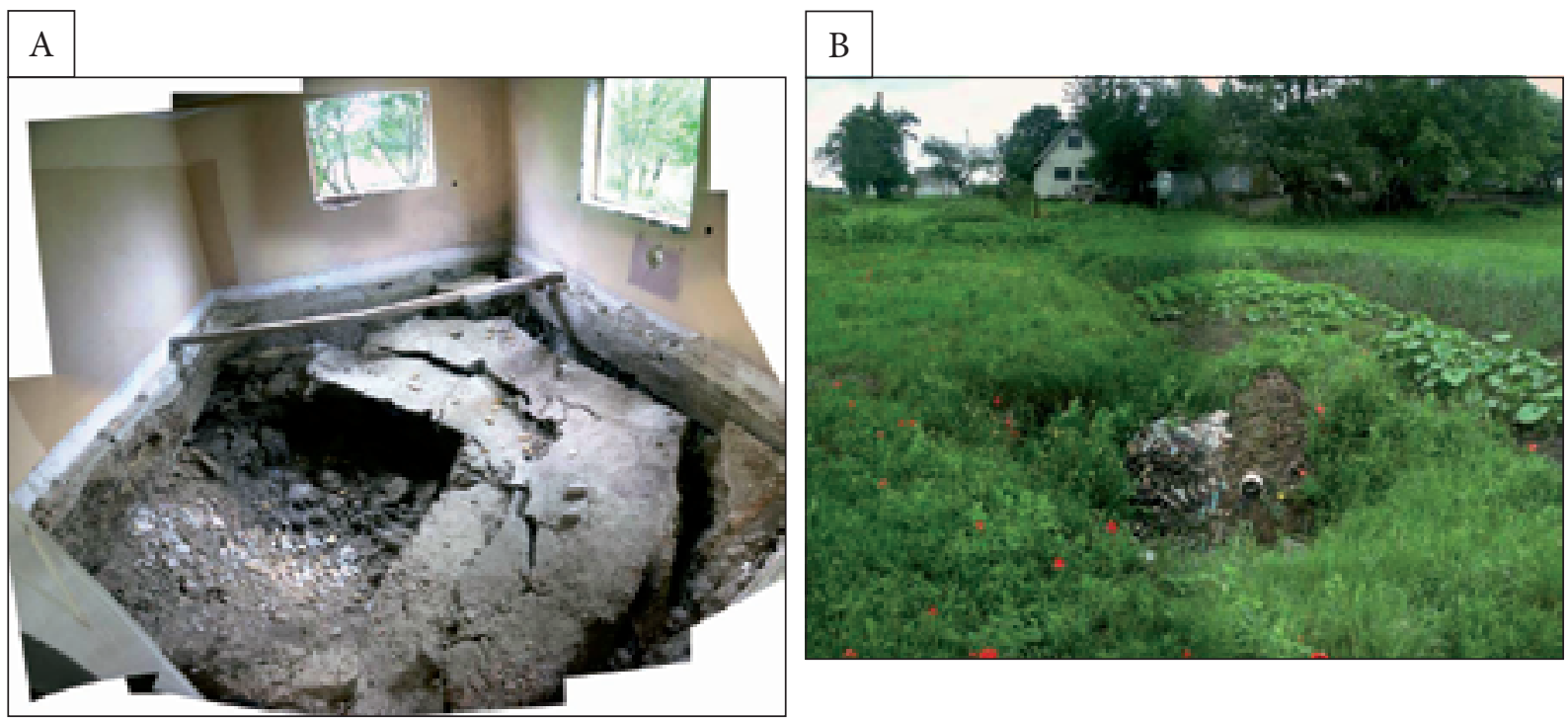

On Orlik Street in Stebnyk, several buildings are located in the area influenced by the earth's surface subsidence and karst failures (Fig. 7). Some of them have been destroyed and some have been damaged. This area stretches along geological boundaries and has dimension: $150 \mathrm{~m} \times 40 \mathrm{~m}$. The findings of the geotechnical work held here in 2000 , on the elucidation of the causes of the karst processes, have not paid sufficient attention to the conditions and factors affecting their development and have not given proper evaluation to the important facts. For example, they had included some local subsidence processes of an east-west direction as a basis although, of course, the whole process was developing in a north-west direction. The placement of the highest areas of the "salt mirror" and all the pressure boreholes (nos. 1, 9, 10,14) were virtually in a straight line, which coincided with the strike of the salt-bearing layers, subsidence zones, etc.

A similar situation of the subsidence of the earth's surface created karst failures at the site of the main power inflow in Mine no. 2 in Stebnyk. At the beginning of 2010, in the Vyshnytsya Valley, an elongated trough subsidence of land and flooding of about $150 \mathrm{~m}$ by $50 \mathrm{~m}$, was formed along geological boundaries, all as a consequence of the technologically activated underground leaching of salts. All surface karst failures found in this area were formed in a straight line.

Fig. 6. Karst failures. Borislav 


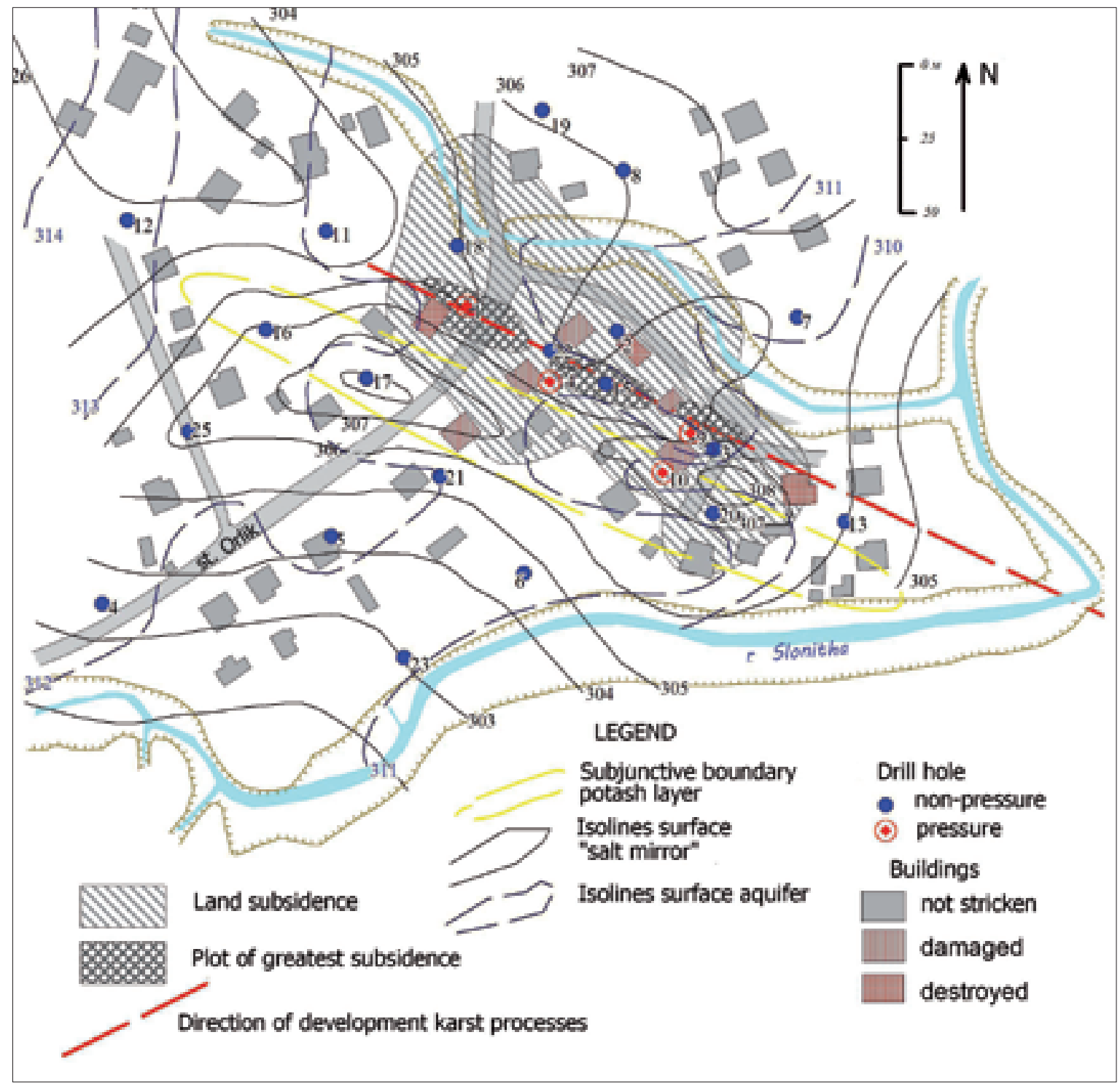

Fig. 7. Location map of exogenic processes. Orlyk street, Stebnyk

\section{CONCLUSIONS}

1. Irrational loading or man-made impacts on the natural environment of the salt-bearing sediments, lead to extreme increases in dangerous karst processes.

2. The spatial development of karst processes in the Carpathian salt deposits are caused by complex geological structures of Miocene sediments.

3. The spatial development of karst processes depends on the heterogeneity of water penetration in plane and section of the salt-bearing sediments. This forms the predominant vector of underground leaching intensity along geological boundaries.

4. Permeability and solubility of salt bearing deposits along the bedding are higher relative to the permeability and solubility across these geological structures.

5. Faults which occur across the strike of geological layers act as a containment of the karst processes along geological borders.

\section{REFERENCES}

Apsse R.F., Voronova L.B., Kozlov S.S. et al., 1966. Otchet po rezul'tatam gidrogeologicheskikh issledovaniy na uchastke techi $v$ shtreke 43/2 rudnika No 1 Stebnitskogo 
kaliynogo kombinata. Fondy Stebnitskogo kaliynogo zavoda, Leningrad.

Blajda R. \& Górecki J., 2001. Wpływ czynników litologiczno-strukturalnych na rozwój krasu solnego w złożu kopalni soli „Wieliczka”. Geologia: kwartalnik Akademii Górniczo-Hutniczej im. Stanisława Staszica w Krakowie, 27, 2-4, 329-340.

Bukowski K. \& Czapowski G., 2009. Salt geology and mining traditions: Kalush and Stebnyk mines (Fore-Carpathian region, Ukraine). Geoturystyka, 3, 18, 27-34.

Frumkin A., 2013. Salt Karst [in:] Treatise on Geomorphology. Vol. 6: Karst Geomorphology, Academic Press, 208-424.

Gaydin A.M., 2008. Vliyaniye tekhnogennoy deyatel'nosti na solyanoy karst. Ekolohiya i pryrodokorystuvannya, $11,42-54$.

Lipnitskiy V.K., 1979. Geologo-gidrogeologicheskiye usloviya proryva vod $v$ kameru 115/1 rudnika No 2 Stkz. Fondy Stebnitskogo kaliynogo zavoda, Leningrad.
Korotkevich G.V., 1970. Solyanoy karst. Nedra, Leningrad.

Pavliuk V., 2010a. Vplyv pryrodno-tekhnohennykh faktoriv na formuvannya ekoloho-heolohichnykh umov v Peredkarpatti (na prykladi rodovyshcha kaliynykh soley "Stebnyk"). Stroitel'stvo i tehnogennaja bezopasnost': sbornik nauchnyh trudov, 33-34, 256-265.

Pavliuk V., 2010b. Vplyv heolohichnykh faktoriv na ekzohenni protsesy miotsenovykh solenosnykh vidkladiv Ukrayinskoho Peredkarpattya. Heolohiya i heokhimiya horyuchykh kopalyn, 2 (151), 89-104.

Stupnitskiy V.M., Zheksimbayev Yu.M., Fedchenko A.I. et al., 1995. Otchet po pereotsenke zapasov kaliynykh soley Stebnitskogo mestorozhdeniya L'vovskoy oblasti. L'vivs'ka GRE, 4174, L'viv

Vakhromeeva V.A., 1959. Treshchynovatost' solyanikh porod karnalytovoy zoni Verkhnekamskoho mestorozhdenyya. Trudy Vsesoyuznogo Instituta Galurgii, 35, 53-70.

Wolkersdorfer Ch., 2008. Water Management at Abandoned Flooded Underground Mines. Springer. 